\title{
ENHANCEMENT OF THE CALORIFIC VALUE OF EMPTY FRUIT BUNCH (EFB) BY ADDING MUNICIPAL SOLID WASTE AS SOLID FUEL IN GASIFICATION PROCESS
}

\author{
Amadou Dioulde Donghol Diallo, Ma'an Fahmi Rashid Alkhatib *, \\ MD. ZAHANGIR ALAM AND MAIZIRWAN MEL \\ Bioenvironmental Engineering Research Centre (BERC), \\ Department of Biotechnology Engineering, Faculty of Engineering, \\ International Islamic University Malaysia, \\ Jalan Gombak, 53100 Kuala Lumpur, Malaysia \\ "Corresponding author:maan@iium.edu.my
}

(Received: $3^{\text {rd }}$ August 2020; Accepted: 23 $3^{\text {rd }}$ January 2021; Published on-line: $4^{\text {th }}$ July 2021)

\begin{abstract}
Empty fruit bunch (EFB), a biomass-based waste, was deemed a potential replacement for fossil fuel. It is renewable and carbon neutral. The efficient management of this potential energy will help to deal with the problem associated with fossil fuels. However, a key parameter for evaluating the quality of raw material (EFB) as a fuel in energy applications is the calorific value $(\mathrm{CV})$. When this $\mathrm{CV}$ is low, then its potential utilization as feedstock will be restricted. To tackle this shortcoming, we propose to add municipal solid waste to enhance energetic value. Thus, two major issues will be solved: managing solid residues and contributing an alternative energy source. This study aimed to investigate the possibility of mixing EFB and municipal solid waste (MSW) to make clean energy that is conscious of the environment (climate change) and sustainable development. The selected MSW, comprising of plastics, textiles, foam, and cardboard, were mixed, with EFB at various ratios. Proximate analysis was used to determine moisture content, ash, volatiles, and fixed carbon, whilst elemental analysis, is used to determine CHNS/O for MSW, EFB and their various mixtures. The CV of each element was also measured. The research revealed a significant increase in the calorific value of EFB by mixing it with MSW according to MSW/EFB ratios: $0.25 ; 0.42 ; 0.66 ; 1.00$ and 1.50 the corresponding calorific values in $(\mathrm{MJ} / \mathrm{kg})$ were $19.77 ; 21.22 ; 22.67 ; 27.04$ and 28.47 respectively. While the calorific value of pure EFB was $16.86 \mathrm{MJ} / \mathrm{kg}$, the mixing of EFB with MSW promoted the increase in the CV of EFB to an average of $23.83 \mathrm{MJ} / \mathrm{kg}$. Another potential environmental benefit of applying this likely fuel was the low chlorine ( 0.21 wt. $\%$ to 0.95 wt. $\%)$ and sulfur concentrations $(0.041 \mathrm{wt} . \%$ to 0.078 wt.\%). This potential fuel could be used as solid refuse fuel (SRF) or refuse-derived fuel (RDF) in a pyrolysis or gasification process with little to no environmental effects.
\end{abstract}

ABSTRAK: Tandan buah kosong (EFB), sisa berasaskan biojisim, adalah berpotensi sebagai pengganti bahan bakar fosil. Ia boleh diperbaharui dan karbon neutral. Pengurusan berkesan pada potensi tenaga ini dapat membantu mengatasi masalah melibatkan bahan bakar fosil. Namun, kunci parameter bagi menilai kualiti bahan mentah (EFB) sebagai bahan bakar dalam aplikasi tenaga adalah nilai kalori (CV). Apabila CV rendah, potensi menjadi stok suapan adalah terhad. Sebagai penyelesaian, kajian ini mencadangkan sisa pepejal bandaran ditambah bagi meningkatkan nilai tenaga. Oleh itu, dua isu besar dapat diselesaikan: mengurus sisa pepejal dan menambah sumber tenaga alternatif. Kajian ini bertujuan mengkaji potensi campuran tandan buah kosong (EFB) dan sisa pepejal bandaran (MSW) bagi menghasilkan tenaga bersih dari 
sudut persekitaran (perubahan iklim) dan pembangunan lestari. Pemilihan MSW, terdiri daripada plastik, tekstil, gabus dan kadbod, dicampurlan dengan pelbagai nisbah EFB. Analisis proksimat telah digunakan bagi mendapatkan kandungan kelembapan, abu, ruapan, dan karbon tetap, manakala analisis asas telah digunakan bagi mendapatkan CHNS/O bersama MSW, EFB dan pelbagai campuran lain. Nilai kalori (CV) setiap elemen turut diukur. Dapatan kajian menunjukkan penambahan ketara dalam nilai kalori EFB dengan campuran bersama MSW berdasarkan nisbah MSW/EFB 0.25; 0.42; 0.66; 1.00 dan 1.50 nilai kalori sepadan $(\mathrm{MJ} / \mathrm{kg}$ ) adalah $19.77 ; 21.22 ; 22.67 ; 27.04$ dan 28.47 masing-masing. Manakala nilai kalori EFB tulen adalah $16.86 \mathrm{MJ} / \mathrm{kg}$, campuran EFB dan MSW menunjukkan kenaikan CV dengan EFB pada purata $23.83 \mathrm{MJ} / \mathrm{kg}$. Antara potensi semula jadi lain adalah dengan mencampurkan bahan bakar ini dengan kalori rendah (0.21 wt. \% kepada 0.95 wt. \%) dan kepekatan sulfur (0.041 wt. \% kepada 0.078 wt.\%). Bahan bakar ini berpotensi sebagai bahan bakar pepejal sampah (SRF) atau bahan bakar yang terhasil dari pepejal sampah (RDF) melalui proses pirolisis atau proses gasifikasi yang sedikit atau tiada kesan langsung terhadap persekitaran.

KEYWORDS: municipal solid waste; empty fruit bunch; calorific value; energy; refuse derived fuel

\section{INTRODUCTION}

Until now, fossil fuels account for almost $84 \%$ of global energy demand [1], and are the most reliable sources of energy. Global production of solid waste increases with an increase in population, leading to environmental pollution [2-4]. According to Massarutto [5] the world energy consumption in 2020 amounts to 196 terawatts (TW) of which 76 for electricity and 120 for heat, and that the potential production of energy from waste maybe double the actual figures. The production of solid waste in the world in 2011 amounted to 2 billion tons of waste during the year. And by 2025, it is estimated that there will be 2.2 billion tons of waste per year, after which 9.5 billion tons of waste will be produced per year in 2050 [3,6,7].

Biomass gasification has a high potential for waste treatment compared to other existing techniques, such as soil filling, incineration, etc., because it can accept a wide range of inputs and may produce multiple useful products. Biomass gasification is an intricate process involving the drying of the feedstock followed by pyrolysis, partial combustion of the intermediates, and finally gasification of the resulting products [7]. The calorific value $(\mathrm{CV})$ is the key parameter for assessing the quality of the feedstock (EFB) as fuel in energy applications. However, this calorific value for EFB is low. In order to improve this calorific value, it must be mixed with other raw materials such as MSW.

Municipal solid and biomass wastes are among the most sustainable sources of energy. Vaish et al. [8], reported that the complexity and the increasing quantity of solid waste had made MSW management a challenging task worldwide. Biomass waste is abundant in many countries over the world, like Malaysia, Indonesia, Guinea Conakry, etc. Among all, biomass waste offers significant opportunities for major, renewable, and suitable environmental-friendly energy sources. These residua, instead of being sent to landfill, could be valorized as a source of energy. Another means to manage MSW is by incineration. Heavy metals like mercury $(\mathrm{Hg})$, cadmium $(\mathrm{Cd})$, arsenic (As), chromium $(\mathrm{Cr})$, and lead $(\mathrm{Pb})$, etc., contained in fly ash can cause air pollution by incineration of MSW and soil and water pollution. The emissions of SOx, NOx, COx, and furans can pollute the environment likewise [2,9]. Moreover, greenhouse gases (GHG) emissions should be reduced by the use of suitable technologies. The third-largest source of GHG is MSW at almost 3-4\% of the global anthropogenic methane, and $18 \%$ of global methane 
emission came from total waste sectors [1]. As indicated in the study by Vaish et al. [8] to achieve the goal of sustainable development, the problem of climate change, and other environmental challenges, must be tackled. MSW is usually, managed through disposal at landfills, which experience severe environmental conditions, such as leachate, high salinity, and GHG generation [10]. Sikarwar et al. [7] estimate that the production of electricity from fossils contributes to pollution and the emission of GHGs.

Solid residues are an alternative to provide environmentally friendly and sustainable energy, that is economically profitable when properly managed and processed $[6,11,12]$. Solid refuse fuel (SRF) and refuse-derived fuel (RDF), can be manufactured in the form of pellets, bricks, etc. It is easy to transport and could contribute to the reduction of pollution problems related to discharge and provides much-needed energy, especially for people suffering a shortage of fuels. Previous studies had promoted SRF and RDF technology, including its characteristics, composition, determination of high heating value, and other parameters [13-17]. In terms of thermal conversion, gasification is one of the many routes to produce clean and environmentally friendly fuel $[18,19]$.

The synthesis gas production by gasification is a process of recovering energy from solid fuels using a high temperature. The quality of RDF depends primarily on the composition of the raw material such as plastic and heavy polymer containers, textiles, foam, etc., which are the basis for the increase in the heating value of fuel oil [13,20-22]. In other words, a higher calorific value is associated, with the content of paper/cardboard, plastic, etc., and their presence in high quantities at $(40-80 \% \mathrm{w} / \mathrm{w}$; weight by weight) can promote the reduction of emissions of $\mathrm{CO}_{2}$.

This study aims to improve the EFB's calorific value by adding specific amounts of MSW. It could be a promising cleaner alternative solution to polluted fossil fuels. The study focused on the quality of the calorific value and special importance was given to reducing the environmental pollution.

\section{MATERIALS AND METHODS}

The data collected for this study was based on proximate and ultimate analysis of municipal solid waste and biomass, followed by a calorific value (CV) measurement.

The analysis investigated the impact of moisture content, temperature, steam to biomass ratio, and particle size on gas composition, etc. Adequate heating values make the material promising for applications such as gasification as RDF and SRF technology $[12,19]$.

\subsection{Feed Materials}

Municipal solid and biomass wastes are abundant in Malaysia; the estimated annual MSW generated is about $13.68 \mathrm{Mt}$ per year, and about $1.17 \mathrm{~kg}$ average rate per capita per day of waste, while the amount of EFB waste was estimated at 7.78 Mt per year [17].

Municipal solid waste (plastics, textile, paper/ cardboard, and foam) was collected at the Gombak MSW transportation station landfill and biomass waste (empty fruit bunch) was collected from Sime Darby Research Center at Carey Island, (Selangor). The samples were ground to an average particle size of approximately $0.5-1 \mathrm{~mm}$, and $0.5-1 \mathrm{~g}$ were used as feed material. 


\subsection{Preparation of Municipal Solid Waste Samples}

Municipal solid and biomass waste had been selected as feedstock for the experiment. Some samples (plastic, cardboard/paper, foam, and textile residue) were chosen and characterized.

These components were selected because data and statistics from National Solid Waste Management Malaysia [17] indicated that they are the major constituents of MSW. Characterized samples were dried in the sun to remove moisture. The samples were prepared to a particle size at $0.5-1 \mathrm{~mm}$ for foam, plastic, textile, cardboard, and empty fruit bunch.

Following these sizes, each sample was weighed into a certain scale to determine the amount needed for mixing. Then, five selected samples with different ratios were examined.

\subsection{Proximate Analysis}

Quantitative determination of moisture content, which has an impact on the calorific value; volatile matter, which represents the matter burns in a gaseous state; ash as inorganic waste material; and fixed carbon which amounts to the solid-state is determined using proximate analysis.

\subsection{Determination of Moisture Content}

Moisture content is considered an important factor that affects the fuel property, seeing that it has an impact on the combustion behavior of the material and its stability. So, the moisture content is determined using ASTM E 871 standards by measuring the weight difference after heating the sample in the oven. It is done by weighing a known mass of the samples in an alumina crucible container and placing them in the oven at a set temperature of $105^{\circ} \mathrm{C}$ for 1 hour. The difference in weight was recorded and calculated as a percentage of the sample weight.

\subsection{Determination of Ash Content}

The experimental procedure includes preparation of MSW and EFB mixed to a welldefined proportion, then the samples of sizes between $0.5 \mathrm{~mm}$ and $1 \mathrm{~mm}$ put in an alumina crucible. The muffle furnace Linn High Therm, type: (LM.212.26 DB006031) was initially purged to remove gaseous combustibles in the furnace. The experiment is performed from ambient temperature up to the maximum temperature of $700{ }^{\circ} \mathrm{C}$ at a constant heating rate of $10^{\circ} \mathrm{C} / \mathrm{min}$ for 30 minutes (Standard method ASTM D1102-84). The sample is then cooled in air, then in a desiccator, and finally weighed.

\subsection{Determination of Volatile Matter}

The experimental procedure includes preparation of MSW and EFB mixed to a welldefined proportion, then, the samples of sizes between $0.5 \mathrm{~mm}$ and $1 \mathrm{~mm}$ were put in an alumina crucible. The muffle furnace Linn High Therm, type: (LM.312.06 DB004031) was initially purged to remove gaseous combustibles in a furnace. The experiment was performed from ambient temperature up to a maximum temperature of $925{ }^{\circ} \mathrm{C}$ at a constant heating rate of $10{ }^{\circ} \mathrm{C} / \mathrm{min}$, for seven minutes (Standard method ASTM E872). Then the sample was cooled in air, then in a desiccator, and weighed. Finally, calculations were performed to determine the percentage of volatile matter in the samples.

The fixed carbon determined through the difference of the sum of the others with the total sample. Equations (1) and (2) are for the determination of fixed carbon and volatile matter, respectively. 


$$
\mathrm{FC}=1-\mathrm{MC}-\mathrm{VM}-\mathrm{Ash}
$$

where: FC, is the fixed carbon in the MSW and EFB that remain in the char during the pyrolysis process after devolatilization. MC stands for moisture content, VM, volatile matter, and Ash is the solid residue of MSW and EFB.

The volatile matter (VM) is determined by the equation:

$$
\mathrm{VM}=\frac{\text { Loss in weight of sample at } 925 \pm 20^{\circ} \mathrm{C}}{\text { weight of sample taken }} * 100
$$

All analyses were performed in duplicate.

\subsection{Ultimate Analysis}

The ultimate analysis is used to determine the percentage of the following elements by standard methods, carbon $(\mathrm{C})$, and hydrogen $(\mathrm{H})$, by (ASTM E-777), nitrogen was performed by (ASTM E-778), chlorine, by (ASTM E- 776-87), and sulfur using (ASTM E-775). All these samples were analyzed in Leco Series 628 CHNS. Oxygen was determined by subtracting the sum of all others cited above from the total of samples.

\subsection{Heating Value}

To perform the calorific value of the MSW and EFB mixture, a Parr 1341 Oxygen Bomb Calorimeter was used for the analysis. It measures the energy released when the sample undergoes complete combustion in the presence of oxygen under a standard condition.

\subsection{Chemical Composition of MSW and EFB}

The chemical composition of MSW and EFB is shown in Table 1. Table 2 illustrates the ratio of the MSW and EFB mixture.

Table 1: Chemical composition of MSW

\begin{tabular}{cccc}
\hline No & Components & $\begin{array}{c}\text { MSW } \\
\text { Percentage (\%) }\end{array}$ & $\begin{array}{c}\text { EFB } \\
\text { Percentage (\%) }\end{array}$ \\
\hline 1 & C & 52.96 & 41.2 \\
2 & $\mathrm{H}$ & 6.58 & 6.36 \\
3 & $\mathrm{O}$ & 36.78 & 47.70 \\
4 & $\mathrm{~N}$ & 0.65 & 0.74 \\
5 & $\mathrm{~S}$ & 0.028 & 0.09 \\
6 & $\mathrm{Cl}$ & 0.24 & 1.010 \\
\hline
\end{tabular}

Table 2: A mixing ratio of MSW and EFB

\begin{tabular}{cc}
\hline Samples No & Mixed elements wt.\% \\
\hline 1 & $20(\mathrm{MSW})+80(\mathrm{EFB})$ \\
2 & $30(\mathrm{MSW})+70(\mathrm{EFB})$ \\
3 & $40(\mathrm{MSW})+60(\mathrm{EFB})$ \\
4 & $50(\mathrm{MSW})+50(\mathrm{EFB})$ \\
5 & $60(\mathrm{MSW})+40(\mathrm{EFB})$ \\
\hline
\end{tabular}




\section{RESULTS AND DISCUSSION}

The analyses of MSW and EFB were carried out individually and for their mixtures in predetermined proportions. Then the calorific value was measured for each sample.

Figure 1 shows the results of the proximate analysis. The minimum value of volatile matter (2.96 wt.\%) was found for EFB, while the maximum amount (3.50 wt.\%) belonged to MSW. EFB has the highest moisture and ash content (15.4 wt.\% and $3.9 \mathrm{wt} \%$ respectively) and the lowest held by MSW (7.5 wt.\% and 2.99 wt.\% respectively). EFB gasification would incur an additional cost for drying due to high moisture content. EFB had the lowest fixed carbon value compared to MSW (77.74 wt.\% and 86 wt.\% respectively). The higher fixed carbon, low moisture content, moderate volatile matter, and ash, thus resulting in higher heating value for MSW. A similar result was reported by Afzanizam et al. [23].

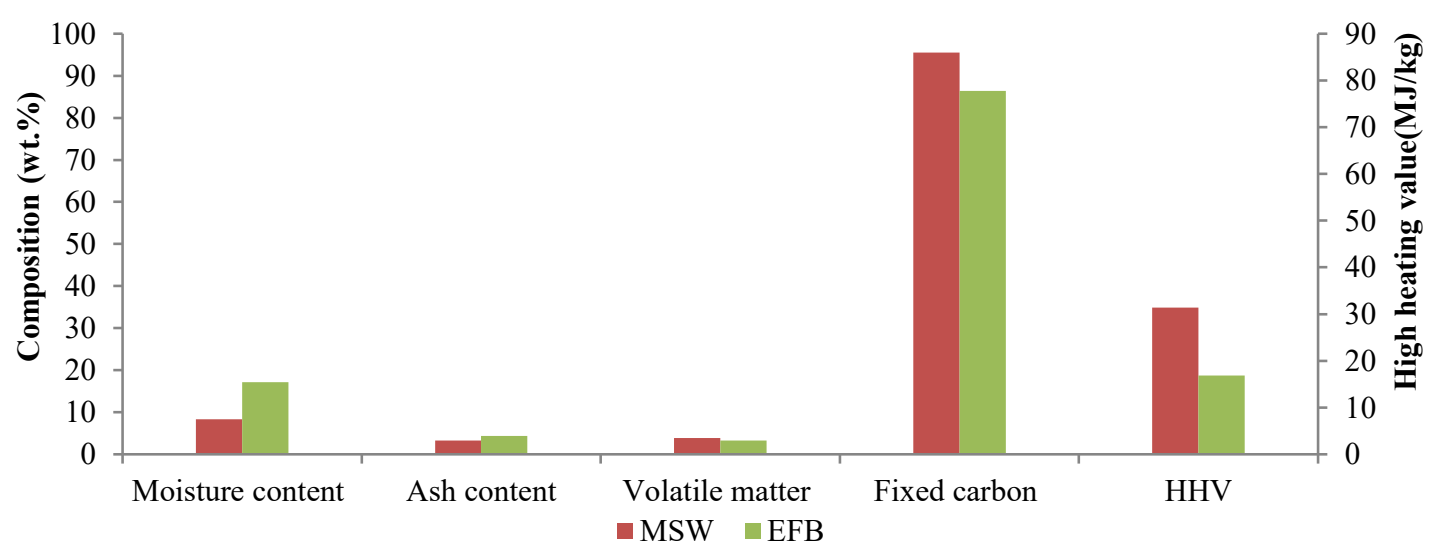

Fig. 1: Proximate analysis of MSW and EFB.

The effect of the mixture (MSW and EFB) ratio on proximate analysis is shown in Fig. 2. It can be seen that the MSW and EFB mixture of 60:40\% has the lowest ash $(2.33$ wt.\%). The highest ash yield (4.22 wt.\%), moisture content (12.43 wt.\%), volatile matter (3.5 wt.\%), and fixed carbon $(92.03$ wt.\%) belong to $(50: 50 ; 20: 80 ; 20: 80$ and $60: 40$ respectively). Moreover, the moisture content and volatile matter decrease as the quantity of MSW supplied in the mixture increases. Also, ash, fixed carbon, and the calorific value increase proportionally with the increase of MSW in the mixture.

The ultimate analysis of pure MSW and EFB is shown in Fig. 3. The MSW has the highest percentage of carbon and hydrogen (52.96 wt.\% and $6.56 \mathrm{wt} . \%$ respectively) and the lowest of oxygen and nitrogen (36.79 wt.\% and $0.65 \mathrm{wt} \%$ respectively). These two elements, carbon, and hydrogen are significant in the fuel because they increase the calorific value. Similar findings were observed by [23,24]. The high quantity of carbon and hydrogen implies that this raw material could be used as a fuel in thermochemical energy conversion like pyrolysis and gasification for syngas production.

It appears that carbon-hydrogen and calorific value increase with the elevation of the amount of MSW in the mixture. In other words, the calorific value increases proportionally, with MSW due to higher carbon and hydrogen content. In contrast, a small amount of nitrogen promotes the quality of the fuel, because it has no calorific value. The highest value of sulfur found in EFB (0.0908 wt.\%) followed by cardboard (0.0886 wt.\%) and textile /foam $(0.0594 \mathrm{wt} . \%)$ and the lowest in plastics $(0.00751 \mathrm{wt} . \%)$ followed by 
MSW (0.0287 wt.\%). Sulfur also increases the value of fuel, but a large amount of sulfur leads to a smoky flame and it is harmful to the environment.

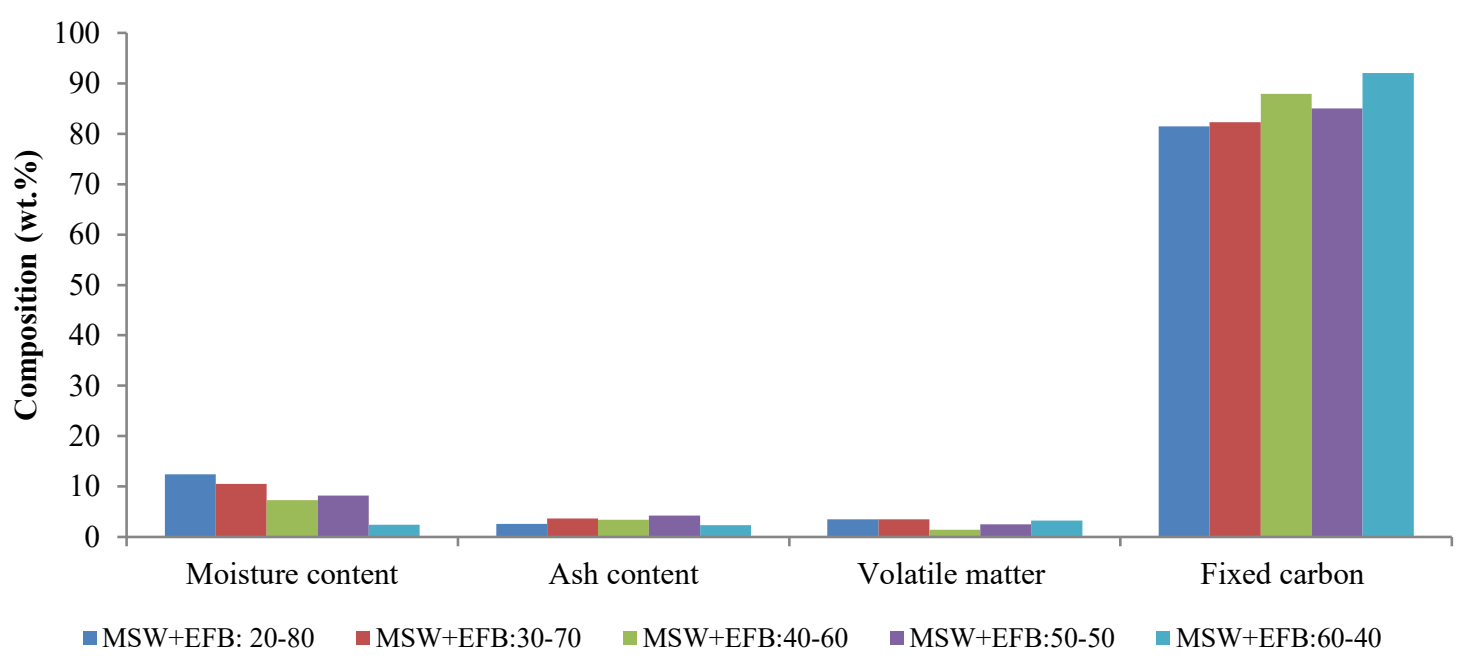

Fig. 2: Proximate analysis of MSW and EFB mixture.

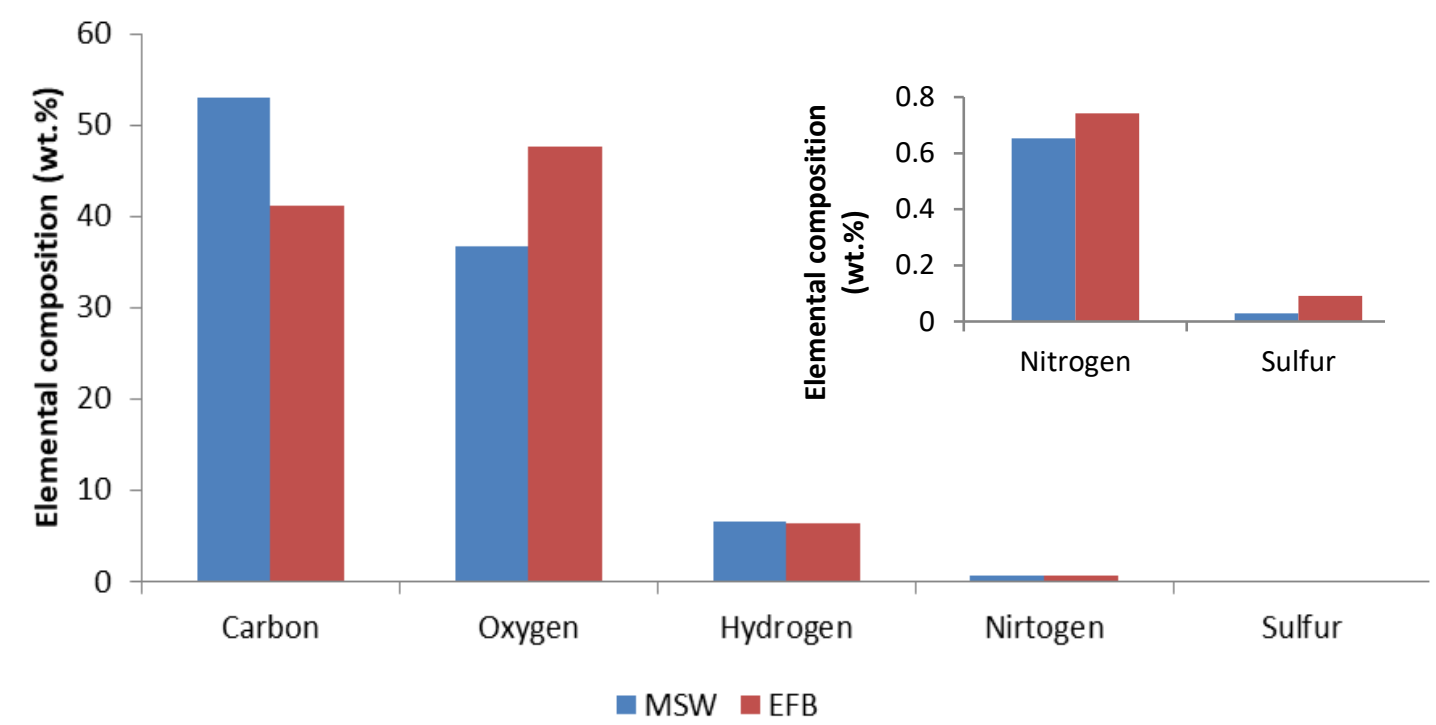

Fig. 3: Ultimate analysis of MSW and EFB (Inset: A zoom in for elemental composition of nitrogen and sulfur for the same materials).

When the proportion of MSW and EFB is (50:50), carbon, and hydrogen got the highest values $(52.50 \mathrm{wt} . \%)$ and $(7.95 \mathrm{wt} . \%)$ respectively, while Oxygen and nitrogen have the smallest concentration (34.71 wt.\%, and $0.33 \mathrm{wt} . \%$ respectively) as seen in Fig. 4.

The comparison of carbon concentrations in Fig. 3 and Fig. 4 demonstrates a gain of 11 wt. \% for EFB, which was 41 wt. \% for pure EFB compared to $52 \mathrm{wt} \% \%$ for MSW and EFB mixture of $50: 50 \%$. The carbon is one of the sources of the calorific value, the mix of MSW and EFB allows increasing the heating value of EFB. Besides, the calorific value of the mixture gradually increases from $19.77 \mathrm{MJ} / \mathrm{kg}$ to $28.47 \mathrm{MJ} / \mathrm{kg}$, as the added amount of MSW increases. It seems likely that these results are due, in fact, to the constituent elements of MSW including carbon, and hydrogen in the plastics portions $(72.84 \mathrm{wt} . \%$ and 9.46 wt.\% respectively). Figure 5 shows the gradual increase in the calorific value of the MSW and EFB mixture. 


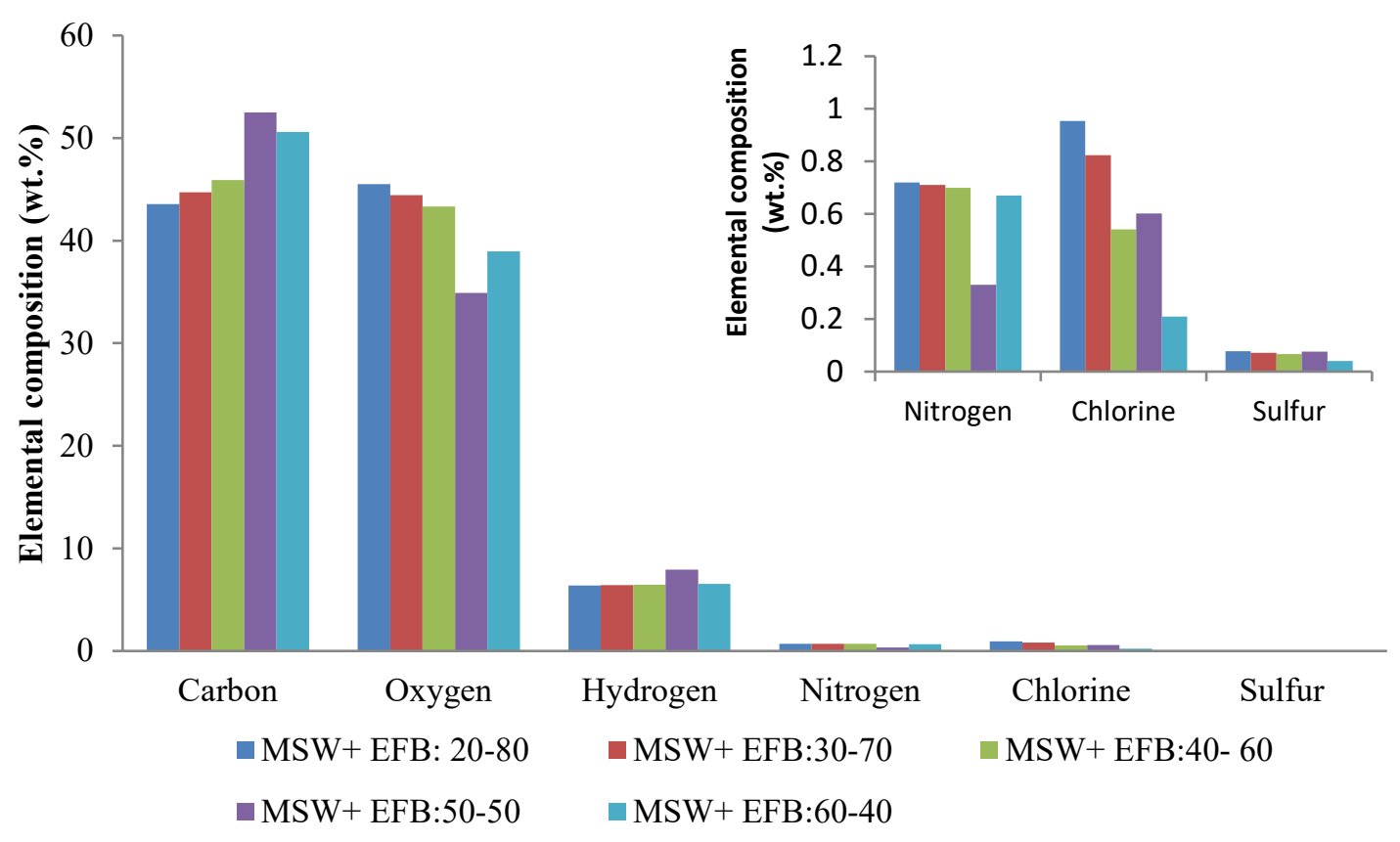

Fig. 4: Ultimate analysis of MSW and EFB mixture (Inset: A zoom in for elemental composition of nitrogen, chlorine and sulfur for the same materials).

Hydrogen sulfide reacts with metals to produce the corresponding metallic sulfide. Thus, chlorine is deposited and poses a technical (i.e. corrosion of the wall of the device) and environmental problem during the gasification process. The concentration of chlorine in these samples varied from (0.154 wt.\% cardboard to $1.010 \mathrm{wt.} \%$ EFB). The average concentration of each component namely cardboard (0.154 wt.\%), plastics (0.166 wt.\%), textile and foam $(0.531 \mathrm{wt.} \%)$, municipal solid waste $(0.249 \mathrm{wt} . \%)$, and empty fruit bunch (1.010 wt.\%) was measured.

The finding shows the mixtures of EFB and MSW have high potential to produce RDF or SRF fuel. Based on the European standard EN 15359, the components used in this study show that MSW with 0.249 wt.\% of $\mathrm{Cl}$, and $29.74 \mathrm{MJ} / \mathrm{kg}$ as low heating value $(\mathrm{LHV})$ is class 1 , textiles $(0.531 \mathrm{wt} . \% \mathrm{Cl})$ class 2 , EFB $(1.010 \mathrm{wt} . \% \mathrm{Cl})$ and $15.09 \mathrm{MJ} / \mathrm{kg}$ as low heating value (LHV) is class 3, thus the mixture EFB and MSW $(0.21 \mathrm{wt} \% \mathrm{Cl})$, and $(0.041 \mathrm{wt} . \% \mathrm{~S})$ is class 1 [16] as shown in Table 3.

The high heating value (HHV) can be converted into the low heating value (LHV) using the following formula:

$$
\mathrm{LHVi}=\mathrm{HHVi}-\mathrm{We} .(9 . \mathrm{Hi}+\mathrm{Wi})
$$

with LHVi : LHV of $i^{\text {th }}$ waste fraction, HHVi: HHV of $i^{\text {th }}$ waste fraction, We: standard heat of evaporation of water $(2.441 \mathrm{MJ} / \mathrm{kg}), \mathrm{Hi}$ : hydrogen content ${ }^{\text {th }}$ waste fraction and $\mathrm{Wi}$ : moisture content of $i^{\text {th }}$ waste fraction [12]. From the result of Fig. 5, where the calorific value was expressed in HHV and the Table 3 where the calorific value was expressed in LHV, formula (3) was used for the calculation of LHV.

The mixture having a ratio of 60 (MSW) and 40 (EFB) has proven to be the best among others as it has the greatest calorific value $(28.47 \mathrm{MJ} / \mathrm{kg})$ and lowest concentrations 
of chlorine $(0.21 \mathrm{wt} . \%)$ and sulfur $(0.041 \mathrm{wt} . \%)$. Thus, in terms of energy and environment, this mixture can be a promising raw material in the gasification process.

Compared to the European standard, the results of this study show that significant pollutant components such as mercury $(\mathrm{Hg})$, arsenic $(\mathrm{As})$, bromine $(\mathrm{Br})$ are not found in these raw materials. Sulfur (S) and chlorine are lower, hence their compliance with the environmental standard to be used as feedstock in the gasification process. Furthermore, in this study, mercury is not found, being an added advantage for this promising fuel

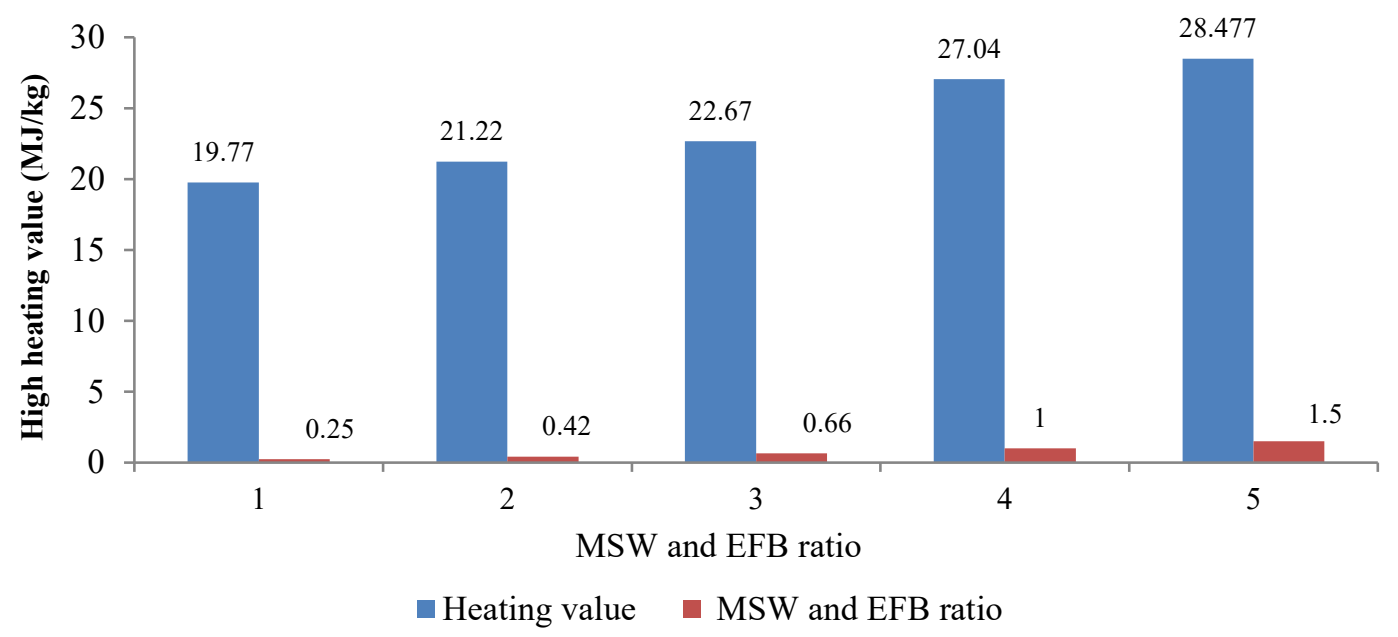

Fig. 5: The high heating value of MSW and EFB mixture.

Table 3: Waste classification criteria as SRF, according to EN 15359 [16]

\begin{tabular}{|c|c|c|c|c|c|c|c|c|c|}
\hline \multirow{2}{*}{ Parameter } & \multirow[t]{2}{*}{ UNIT } & \multicolumn{5}{|c|}{ CLASSES } & \multicolumn{3}{|c|}{ CURRENT STUDY } \\
\hline & & 1 & 2 & 3 & 4 & 5 & MSW & EFB & $\begin{array}{c}60(\mathrm{MSW})+ \\
40 \text { (EFB) }\end{array}$ \\
\hline Lower heating value & $\mathrm{MJ} / \mathrm{kg}$ & $\geq 25$ & $\geq 20$ & $\geq 15$ & $\geq 10$ & $\geq 3$ & 29.74 & 15.1 & 26.98 \\
\hline Chlorine content & $\%(\mathrm{w} / \mathrm{w})$ & $\leq 0.2$ & $\leq 0.6$ & $\leq 1.0$ & $\leq 1.5$ & $\leq 3$ & 0.249 & 1.01 & 0.21 \\
\hline Mercury content & $\mathrm{Mg} / \mathrm{MJ}$ & $\leq 0.02$ & $\leq 0.03$ & $\leq 0.08$ & $\leq 0.15$ & $\leq 0.5$ & 0 & 0 & 0 \\
\hline
\end{tabular}

\section{CONCLUSIONS}

The goal of this investigation was to assess the efficacy of mixing municipal solid waste and biomass to improve the calorific value. The materials establish that the concentrations of carbon, hydrogen, nitrogen, and oxygen obtained from the analyses carried out are sufficient to produce a fuel of high calorific value. Moreover, the environmental parameters $(\mathrm{Cl}$ and $\mathrm{S})$ are within the prescribed standards. These findings show that the calorific value (CV) of EFB which is $16.86 \mathrm{MJ} / \mathrm{kg}$ can be enhanced depending on the quantity of added MSW and can reach up to $28.47 \mathrm{MJ} / \mathrm{kg}$. This potential energy can be used as a raw material in a pyrolysis or gasification process with little to no environmental impacts.

\section{REFERENCES}

[1] Kumar A, Samadder SR. (2017) A review on technological options of waste to energy for effective management of municipal solid waste. Waste Management, 69: 407-422. https:// doi.org/10.1016/j.wasman.2017.08.046 
[2] Liu Z. (2019) Gasification of municipal solid wastes: a review on the tar yields. EnergySources, Part A: Recovery, Utilization and Environmental Effects, 41(11): 1296-1304. https://doi.org/10.1080/15567036.2018.1548508

[3] Lombardi L, Carnevale E, Corti A. (2014) A review of technologies and performances of thermal treatment systems for energy recovery from waste. Waste Management, 37: 26-44. https://doi.org/10.1016/j.wasman.2014.11.010

[4] Makarichi L, Jutidamrongphan W, Techato K. (2018) The evolution of waste-to-energy incineration: A review. Renewable and Sustainable Energy Reviews, 91: 812-821. https://doi.org/10.1016/j.rser.2018.04.088

[5] Massarutto A. (2014) Economic aspects of thermal treatment of solid waste in a sustainable WM system. Waste Management. https://doi.org/10.1016/j.wasman.2014.08.024

[6] Beyene HD, Werkneh AA, Ambaye TG. (2018) Current updates on waste to energy (WtE) technologies: A review. Renewable Energy Focus, 24: 1-11. https://doi.org/10.1016/j.ref.2017.11.001

[7] Sikarwar VS, Zhao M, Clough P, Yao J, Zhong X, Memon MZ, Shah N, Anthony EJ, Fennell PS. (2016) An overview of advances in biomass gasification. Energy and Environmental Science, 9(10): 2939-2977. https://doi.org/10.1039/c6ee00935b

[8] Vaish B, Sharma B, Srivastava V, Singh P, Ibrahim MH, Singh RP. (2019) Energy recovery potential and environmental impact of gasification for municipal solid waste. Biofuels, 10(1): 87-100. https://doi.org/10.1080/17597269.2017.1368061

[9] Nobre C, Gonçalves M, Vilarinho C. (2019) A brief assessment on the application of torrefaction and carbonization for refuse derived fuel Upgrading. Lecture Notes in Electrical Engineering, 505: 633-640. https://doi.org/10.1007/978-3-319-91334-6_86

[10] He P, Chen L, Shao L, Zhang H, Lü F. (2019) Municipal solid waste (MSW) landfill: A source of microplastics? Evidence of microplastics in landfill leachate. Water Research, 159: 38-45. https://doi.org/10.1016/j.watres.2019.04.060

[11] Brunner PH, Rechberger H. (2015) Waste to energy - key element for sustainable waste management. Waste Management, 37: https://doi.org/10.1016/j.wasman.2014.02.003

[12] Chol ON, Song PH, Chol SY, Hyok RY, Nam KY. (2018) Environmental effects A feasibility study of energy recovery of RDF from municipal solid waste. Energy Sources, Part A: Recovery, Utilization, and Environmental Effects, 40(24): 2914-2922. https://doi.org/10.1080/15567036.2018.1514431

[13] De Gisi S, Chiarelli A, Tagliente L, Notarnicola M. (2018) Energy, environmental and operation aspects of a SRF-fired fluidized bed waste-to-energy plant. Waste Management, 73: 271-286. https://doi.org/10.1016/j.wasman.2017.04.044

[14] Elisabete M, Brás I, Silva ME. (2017) Refuse Derived Fuel from Municipal Solid Waste rejected fractions- Case Study The 15th International a Symposium on District Heating and Cooling. Energy Procedia, 120: 349-356. https://doi.org/10.1016/j.egypro.2017.07.227

[15] Farzad S, Mandegari MA, Görgens JF. (2016) A critical review on biomass gasification, cogasification, and their environmental assessments. Biofuel Research Journal, 3(4): 483-495. https://doi.org/10.18331/BRJ2016.3.4.3

[16] Garcés D, Díaz E, Sastre H, Ordóñez S, González-lafuente JM. (2015) Evaluation of the potential of different high calorific waste fractions for the preparation of solid recovered fuels. Waste Management, 47(B): 164-173. https://doi.org/10.1016/j.wasman.2015.08.029

[17] Hamzah, N., Tokimatsu, K., \& Yoshikawa, K. (2019). Solid fuel from oil palm biomass residues and municipal solid waste by hydrothermal treatment for electrical power generation in Malaysia: A review. Sustainability (Switzerland), 11(4): 1-23. https://doi.org/10.3390/su11041060

[18] Abdullah N, Sulaiman F, Taib RM. (2013) Characterization of banana (Musa spp.) plantation wastes as a potential renewable energy source. AIP Conference Proceedings, 1528: 325-330. https://doi.org/10.1063/1.4803618

[19] Aluri S, Syed A, Flick DW, Muzzy JD, Sievers C. (2018) Pyrolysis and gasification studies of model refuse derived fuel (RDF) using thermogravimetric analysis. Fuel Processing Technology, 179: 154-166. https://doi.org/10.1016/j.fuproc.2018.06.010 
[20] Nizami AS, Shahzad K, Rehan M, Ouda OKM, Khan MZ, Ismail IMI, Almeelbi T, Basahi J. M, Demirbas A. (2017) Developing waste biorefinery in Makkah: A way forward to convert urban waste into renewable energy. Applied Energy, 186: 189-196. https://doi.org/10.1016/j.apenergy.2016.04.116

[21] Ouda OKM, Raza SA, Nizami AS, Rehan M, Al-waked R, Korres NE. (2016) Waste to energy potential: A case study of Saudi Arabia. Renewable and Sustainable Energy Reviews, 61: 328-340. https://doi.org/10.1016/j.rser.2016.04.005

[22] Komilis D, Kissas K, Symeonidis A. (2014) Effect of organic matter and moisture on the calorific value of solid wastes: An update of the Tanner diagram. Waste Management, 34(2): 255. https://doi.org/10.1016/j.wasman.2013.09.023

[23] Afzanizam N, Nazri M, Jaafar M, Tung C, Johan N. (2015) A review of palm oil biomass as a feedstock for syngas fuel technology. Jurnal Teknologi, 5: 13-18.

[24] Onoja E, Chandren S, Abdul Razak FI, Mahat NA, Wahab RA. (2018) Oil alm (Elaeis guineensis) biomass in Malaysia: The present and future prospects. Waste and Biomass Valorization, 10: 2099-2117. https://doi.org/10.1007/s12649-018-0258-1 